\title{
Grafted Melons Irrigated with Fresh or Effluent Water Tolerate Excess Boron
}

\author{
Menahem Edelstein ${ }^{1}$ \\ Department of Vegetable Crops, Agricultural Research Organization, Newe Ya'ar Research Center, \\ P.O. Box 1021, Ramat Yishay 30-095, Israel \\ Meni Ben-Hur and Zui Plaut \\ Institute of Soil, Water and Environmental Sciences, ARO, The Volcani Center, P.O. Box 6, Bet Dagan \\ 50-250, Israel
}

\begin{abstract}
AdDitional INDEX words. boron tolerance, Cucurbita, effluent, grafting
Abstract. The effects of boron and effluent (treated sewage water) on vegetative growth, fruit yield, and boron uptake of grafted and nongrafted melons (Cucumis melo L. cv. Arava) were studied. Nongrafted melon plants and melon plants grafted onto the commercial Cucurbita maxima Duchesne $\times$ Cucurbita moschata Duchesne rootstock 'TZ-148' were grown in pots filled with perlite in a heated greenhouse and were irrigated with fresh water or effluent. The two irrigation waters contained boron in five concentrations ranging from 0.1 to $10.4 \mathrm{mg} \cdot \mathrm{L}^{-1}$. The boron concentration in the plants increased linearly with that in the irrigation water. The highest boron concentrations were found in old leaves, the lowest in the fruit, and intermediate concentrations were noted in the roots. The boron concentrations were, in general, significantly lower in grafted than nongrafted plants, possibly because the root system of the former had higher selectivity and lower boron absorption than that of the latter. Fruit yield and dry weight accumulation in shoots and roots decreased linearly as the boron concentration in the irrigation water increased, the nongrafted plants were more sensitive than grafted ones to the boron level, and both were more sensitive under fresh water irrigation than under effluent irrigation. It is suggested that the higher boron sensitivity of the root systems of the nongrafted plants probably decreased their capability to absorb water and nutrients, which in turn sharply reduced their fruit yields.
\end{abstract}

Boron deficiency and boron toxicity are important micronutrient factors that affect the productivity of cultivated crops in many parts of the world. Although boron deficiency might occur in humid regions, boron toxicity can be a serious problem in arid and semiarid regions (Nable et al., 1997). Excess boron in the root zone could reflect its high content in the local soils, which originates in mineral weathering (Keren and Bingham, 1985), or could indicate a high concentration in the irrigation water, particularly when saline or treated sewage water (effluent) is used (Feigin et al., 1991).

Effluent differs from fresh water in its electrical conductivity (EC), $\mathrm{pH}$, and concentrations of microelements, nutrients, and dissolved organic matter, all of which are significantly higher, in general, than in fresh water (Ben-Hur, 2004). Boron is a common microelement in raw sewage and, in many cases, treatment of this sewage does not decrease its concentration (Ben-Hur, 2004; Tsadilas, 1997). For example, the average boron concentrations in some Israeli effluents range from 0.43 to $0.65 \mathrm{mg} \cdot \mathrm{L}^{-1}$ (Ben-Hur, 2004).

The reuse of effluent for irrigation is increasing in arid and semiarid regions, because of the shortage in fresh water and the pressure to avoid disposal of nutrient-rich effluents into freshwater bodies or the sea. Long-term irrigation with effluent

Received for publication 19 Oct. 2006. Accepted for publication 30 Mar. 2007. The authors gratefully acknowledge the support for this study provided by the Chief Scientist's Fund of the Ministry of Agriculture and Rural Development of the State of Israel under research project 255-0663-04.

Contribution from the Agricultural Research Organization, the Volcani Center, Bet Dagan, Israel. No. 123/2005.

The authors thank Mr. A. Porat, Ms. L. Liab, and Mr. F. Baumkoler of the Agricultural Research Organization for technical assistance.

${ }^{1}$ Corresponding author. E-mail: medelst@volcani.agri.gov.il. could increase boron concentration in the soil to high levels, because of adsorption by clay minerals and organic matter (Yermiyahu et al., 1995). This increase may intensify the problem of boron toxicity in cultivated fields (Halliwell et al., 2001).

The negative effects of excess boron concentrations on the yields of crops under irrigation with fresh water are widely documented (e.g., Ben-Gal and Shani, 2003; Eaton, 1994; Edelstein et al., 2005; El-Sheikh et al., 1971; Goldberg et al., 2003; Lauter et al., 1989; Marschner, 1989). El-Sheikh et al. (1971) found 50\% decreases in vegetative growth of cucumber (Cucumis sativus L.), squash (Cucurbita L.), muskmelon (Cucumis melo), and corn (Zea mays L.) when boron concentrations in the nutrient solutions were 6,12 , and $16 \mathrm{mg} \cdot \mathrm{L}^{-1}$ respectively. Lauter et al. (1989) showed that peanut (Arachis hypogaea L. cv. Shulamit) yield was reduced when boron concentration in the nutrient solution exceeded a threshold of $3.1 \mathrm{mg} \cdot \mathrm{L}^{-1}$. Goldberg et al. (2003) found a linear increase of boron concentration in leaves of 'Top Mark' melon as boron concentration in the soil solution (1 soil: 1 water) increased up to $18 \mathrm{mg} \cdot \mathrm{L}^{-1}$, causing chlorosis in the leaf margins and fruit yield reduction.

Because high boron concentrations in the irrigation water are occasionally associated with salinity, the interaction of salinity and high boron concentrations in the irrigation water and their effects on plant development and production have been the subject of a number of investigations. Poss et al. (1998) found that the relative area of injuries to the leaves of eucalyptus trees (Eucalyptus camaldulensis D.), even with high concentrations of boron in the irrigation water, was reduced by increased salinity. Ben-Gal and Shani (2002) showed that the decreases in yield and transpiration of tomatoes (Esculentum 
lycopersicum L.) exposed to boron were much less in the presence of salinity (mostly $\mathrm{NaCl}$ ). Edelstein et al. (2005) found that irrigation of melons with saline water reduced both the concentration of boron in the leaves and the sensitivity of the plants to high boron concentrations in the water. They hypothesized that the low boron uptake under high-salinity irrigation was mainly a result of reduced transpiration.

The combined effects of effluent irrigation and high boron concentrations on plant growth and yield have been investigated much less. Johns and McConchie (1994) found that irrigation with effluent that contained $81 \%$ more boron than tap water had no negative effect on banana (Musa cavendishi L.) plant size. In citrus (Citrus sinensis L.), boron concentration in leaves was below toxic levels in plants that were irrigated with effluent containing higher boron concentrations than groundwater, and the growth and fruit quality parameters of the trees were unaffected by the high boron concentrations (Reboll et al., 2000). Zekri and Koo (1994) found that boron concentrations in citrus leaves were higher when the plant was irrigated with effluent than they were with well water, but were still below toxic levels. It should be noted, however, that in these studies no distinction was made between the effect of boron and those of other effluent constituents, nor was it determined whether the observed plant responses were the result of the boron content or of other properties of the effluent.

Edelstein et al. (2005) showed that melon plants grafted on Cucurbita (TZ-148) rootstocks accumulated less boron in the vegetative shoot than nongrafted melons exposed to similar boron concentrations in the irrigation water. This was attributed to the exclusion of some boron by the Cucurbita rootstocks, which decreased its concentration in the grafted shoot. In addition, Edelstein et al. (2005) found that the fruit yield of the grafted plants was less affected by boron accumulation in the leaves than that of nongrafted plants, but they offered no explanation of this phenomenon. Grafting was also found to improve the salinity tolerance of tomato by limiting the transport of sodium and chloride to the shoot (Estan et al., 2005).

The objectives of the current study were 1) to study the effects of effluent and of its interaction with various boron concentrations in the irrigation water on boron concentration and uptake in the various organs of nongrafted and grafted melon plants, and 2) to determine the factors responsible for the boron accumulation in plant organs and their effects on growth and fruit yield of nongrafted and grafted plants.

\section{Materials and Methods}

'Arava' melon (Cucumis melo ssp. melo L. Reticulatus Group) plants, nongrafted and grafted onto the commercial Cucurbita maxima $\times$ Cucurbita moschata (pumpkin, squash) rootstock 'TZ148' (Edelstein et al., 1999), were used in this study. Seedlings of the grafted and nongrafted melons were planted on 17 Dec. 2002 in 10-L pots containing perlite (no. 2; Agrical, Habonim, Israel), one seedling per pot, and were grown in a heated greenhouse at the Newe Ya'ar Research Center in northern Israel.

Plants were irrigated with fresh water or treated domestic sewage water. Both types of water were analyzed, and their ionic compositions and concentrations are presented in Table 1. The dissolved organic matter in the water was determined with a combustion TOC analyzer (Skalar Analytical B.V., Breda, the Netherlands), and the concentrations of trace elements were determined by inductively coupled plasma emission spectroscopy [ICPES (Spectro GmbH, Kleve, Germany)]. The pH, EC, and sodium absorption ratio values, and the concentrations of $\mathrm{Cl}^{-}$and other nutrients in the waters were determined by standard methods (U.S. Department of Agriculture, 1954).

Boric acid $\left(\mathrm{H}_{3} \mathrm{BO}_{3}\right)$ was added to the two irrigation solutions in amounts equivalent to boron concentrations of $0,5,6.5,8.5$, and $10 \mathrm{mg} \cdot \mathrm{L}^{-1}$; any initial boron content was not taken into account. The nongrafted and grafted plants were irrigated with either fresh water or effluent, each containing each of the boron concentrations. All treatments (two plant types, two water types, and five boron concentrations) were repeated five times (five pots) in a fully randomized factorial design. The plants were irrigated to excess five times per day by a drip system, so that most of the excess salt and boron were leached out of the pots. A fertilizer containing $7 \mathrm{~N}-1.4 \mathrm{P}-5.8 \mathrm{~K}$ was applied via the irrigation water. The concentration of the fertilizer in the fresh irrigation water was $0.2 \%$ (by volume), whereas in the effluent irrigation water the inorganic $\mathrm{N}$ in the effluent was taken into account, and the fertilizer was added in quantities that resulted in similar concentrations of inorganic $\mathrm{N}$ to those in the fresh water. After the addition of the fertilizers, the average values of the $\mathrm{pH}$ and $\mathrm{EC}$ were 7.3 and $1.6 \mathrm{dS} \cdot \mathrm{m}^{-1}$ respectively in the fresh water, and 7.7 and $2.2 \mathrm{dS} \cdot \mathrm{m}^{-1}$ respectively in the effluent water. Drainage water from the plant pots was collected at various times during the season, and the $\mathrm{pH}$ and $\mathrm{EC}$ were recorded.

Fully mature (i.e., "full slip") fruit were harvested during Mar. and Apr. 2003, and the number of fruit and their weight

Table 1. Chemical analysis of samples that were taken at different dates from the effluent and fresh water that were used for irrigation of nongrafted and grafted melon plants.

\begin{tabular}{|c|c|c|c|c|c|c|c|c|c|c|c|c|c|c|c|c|}
\hline \multirow[b]{3}{*}{ Date } & \multirow[b]{3}{*}{$\mathrm{pH}$} & \multirow[b]{2}{*}{$\mathrm{EC}$} & \multirow[b]{2}{*}{$\mathrm{Cl}^{-}$} & \multirow[b]{3}{*}{ SAR } & \multicolumn{4}{|c|}{ Nutrients } & \multirow{3}{*}{$\begin{array}{c}\mathrm{K}^{+} \\
\left(\mathrm{meq} \cdot \mathrm{L}^{-1}\right)\end{array}$} & \multicolumn{7}{|c|}{ Microelements } \\
\hline & & & & & DOM & $\mathrm{N}-\mathrm{NH}_{4}$ & $\mathrm{~N}-\mathrm{NO}_{3}$ & $\mathrm{P}-\mathrm{PO}_{4}$ & & $\mathrm{~B}$ & $\mathrm{Sr}$ & $\mathrm{Zn}$ & $\mathrm{Cu}$ & $\mathrm{Ni}$ & $\mathrm{Fe}$ & $\mathrm{Mn}$ \\
\hline & & \multicolumn{2}{|c|}{$\left(\mathrm{dS} \cdot \mathrm{m}^{-1}, \mathrm{meq} \cdot \mathrm{L}^{-1}\right)$} & & \multicolumn{4}{|c|}{$\left(\mathrm{mg} \cdot \mathrm{L}^{-1}\right)$} & & \multicolumn{7}{|c|}{$\left(\mu \mathrm{g} \cdot \mathrm{L}^{-1}\right)$} \\
\hline \multicolumn{17}{|c|}{ Effluent } \\
\hline 29 Dec. 2002 & 8.5 & 1.9 & 10.5 & 5.6 & 61.8 & 15.7 & 2.3 & 7.2 & 0.65 & 401 & 566 & 35 & 10 & 13 & 949 & 84 \\
\hline 27 Jan. 2003 & 8.0 & 2.0 & 9.8 & 5.2 & 31.5 & 12.0 & 3.8 & 9.7 & 0.71 & 381 & 582 & 35 & 7 & 10 & 588 & 95 \\
\hline 27 Feb. 2003 & 8.7 & 2.0 & 9.3 & 5.0 & 32.4 & 12.7 & 6.7 & 7.7 & 0.68 & 337 & 523 & 46 & BDV & 11 & 643 & 67 \\
\hline Avg & 8.5 & 2.0 & 9.9 & 5.3 & 39.0 & 13.7 & 3.8 & 7.9 & 0.68 & 373 & 550 & 32 & 12 & 11 & 767 & 79 \\
\hline \multicolumn{17}{|c|}{ Fresh water } \\
\hline Avg & 7.2 & 1.0 & 7.0 & 2.5 & $\approx 0$ & $\approx 0$ & 1.5 & 0.04 & 0.16 & 100 & 573 & 54 & BDV & $\mathrm{BDV}$ & 9 & 7 \\
\hline
\end{tabular}

$\mathrm{BDV}$, below deductive value; DOM, dissolve organic matter; EC, electrical conductivity; SAR, sodium absorption ratio. 
were recorded for each plant. Fruit were cut into small pieces, dried at $60{ }^{\circ} \mathrm{C}$ for $96 \mathrm{~h}$, and stored pending chemical analysis. At the end of the experiment the vegetative shoots were harvested and the root systems were separated from the perlite, washed gently in deionized water, dried at $60{ }^{\circ} \mathrm{C}$ for $48 \mathrm{~h}$, weighed, and stored pending chemical analysis.

In three of the five replications of each treatment, the boron concentrations in the old leaves, in the root system, and in the fruit were determined. Boron was analyzed by ashing $0.25 \mathrm{~g}$ of each sample in a furnace at $600{ }^{\circ} \mathrm{C}$ for $5 \mathrm{~h}$, adding $5 \mathrm{~mL} 1 \mathrm{M}$ $\mathrm{HCl}$ to the cooled ash, filtering the solution after $15 \mathrm{~min}$, and determining boron concentration by ICPES.

The data were subjected to analysis of variance and Tukey's honestly significant difference to determine the statistical significance of differences between treatments. Regression analysis was conducted to identify relationships between some measured parameters.

\section{Results and Discussion}

Concentrations of boron in the old leaves, root system, and fruit of grafted and nongrafted melon plants are presented in Fig. 1 as a function of the boron concentrations in the irrigation water. For both nongrafted and grafted plants, and for both water types, the boron concentrations in each plant organ increased linearly and significantly $\left(r^{2}>0.8\right.$, Fig. 1) with increasing boron concentration. The highest boron concentrations, ranging from 150 to $2224 \mathrm{mg} \cdot \mathrm{kg}^{-1}$, were found in old leaves; the lowest concentrations, ranging from 10 to $100 \mathrm{mg} \cdot \mathrm{kg}^{-1}$, were in the fruit; and intermediate concentrations, ranging from 47 to $282 \mathrm{mg} \cdot \mathrm{kg}^{-1}$, were found in the roots. Because the greatest transpiration was via the leaves, these results are a good indication that transpiration was the major determining factor for boron accumulation in plant organs. Dannel et al. (2000) also found that transport of boron with the transpiration stream resulted in its preferential accumulation in readily transpiring organs.

Boron concentrations in the various organs of the grafted plants were, in general, lower than those in the corresponding organs of the nongrafted plants, with both water types (Fig. 1), and the differences increased with increasing boron concentration in the irrigation water. Similar results were obtained by Edelstein et al. (2005) in old leaves of nongrafted and grafted melon plants that were irrigated with fresh $\left(\mathrm{EC}, 1.8 \mathrm{dS} \cdot \mathrm{m}^{-1}\right)$ and saline (EC, $4.6 \mathrm{dS} \cdot \mathrm{m}^{-1}$ ) water. However, although Edelstein et al. (2005) found that an increase of salinity in the irrigation water from EC of 1.8 to $4.6 \mathrm{dS} \cdot \mathrm{m}^{-1}$ decreased leaf boron concentration significantly in both grafted and nongrafted plants, this did not happen under effluent irrigation in the current study. Boron concentrations in the three organs of each plant type were unaffected whether irrigation was with fresh water or effluent (Fig. 1). Probably, the relatively low EC $\left(2 \mathrm{dS} \cdot \mathrm{m}^{-1}\right)$ in the effluent was not sufficient to decrease boron absorption by the melon plants.

The lower boron concentration in the leaves of the grafted melon plants than in those of the nongrafted could be mainly the result of the differences in the properties of the root systems of the two plant types. The root system could affect boron concentration in the shoot in three different ways.

First, boron could accumulate and bind in the root system, which would limit its movement toward the shoot, as reported for some fruit trees (Elmotaium et al., 1994; Papadakis et al., 2004). It should be noted, however, that in the current study boron concentrations in the root systems of both grafted and nongrafted melon plants were relatively low and, moreover, the boron concentrations in the roots of the nongrafted plants were similar to or higher than those in the roots of the grafted ones (Fig. 1B). Thus, it can be concluded that the lower boron concentrations in the leaves of the grafted plants than in those in the nongrafted ones were not the result of greater boron accumulation and attachment in the roots of the grafted plants than in those of the nongrafted ones.

Second, changes incited by root activities in the chemical properties of the solution in the root zone could, in turn, affect the boron absorption by the plant. Because the perlite substrate is an inert material, it is

Fig. 1. (A-C) Boron concentrations in old leaves, root systems, and fruit of grafted and nongrafted melon plants as functions of boron concentrations in effluent and in fresh irrigation water, including the regression equations. Bars indicate $\mathrm{SE}$; * indicates that the regression line is statistically significant at the 0.05 level. 
suggested that the composition of the leachate from the plant pots represented the composition of the solution in the vicinity of the root system. The average values of $\mathrm{EC}$ and $\mathrm{pH}$ in the leachate from the pots on different sampling dates, for both types of plant and for both irrigation waters, are presented in Fig. 2. It was valid to calculate these average values from the $\mathrm{pH}$ and EC values in all the boron treatments for each plant and irrigated water type, because no significant differences between these values in the various boron treatments were found. In general, the EC in the leachate increased with time, which indicates a slight accumulation of salt in the root zone during the growing period. The EC values in the leachate were significantly higher under irrigation with effluent than with fresh water, with both plant types and at each sampling date. The higher EC in the applied effluent than in the applied fresh water (Table 1) was sufficient to account for this higher EC. No significant differences in the EC values in the leachate were observed between the grafted and nongrafted plants, under irrigation with either water (Fig. 2A), indicating that the differences between the root systems of the nongrafted and the grafted plants did not affect the EC of the solution in the vicinity of the root.

The $\mathrm{pH}$ values in the leachates of the two plant types in both irrigation water treatments decreased with passing time, and the decreases were faster with nongrafted than with grafted ones, and with fresh water than with effluent (Fig. 2B). This
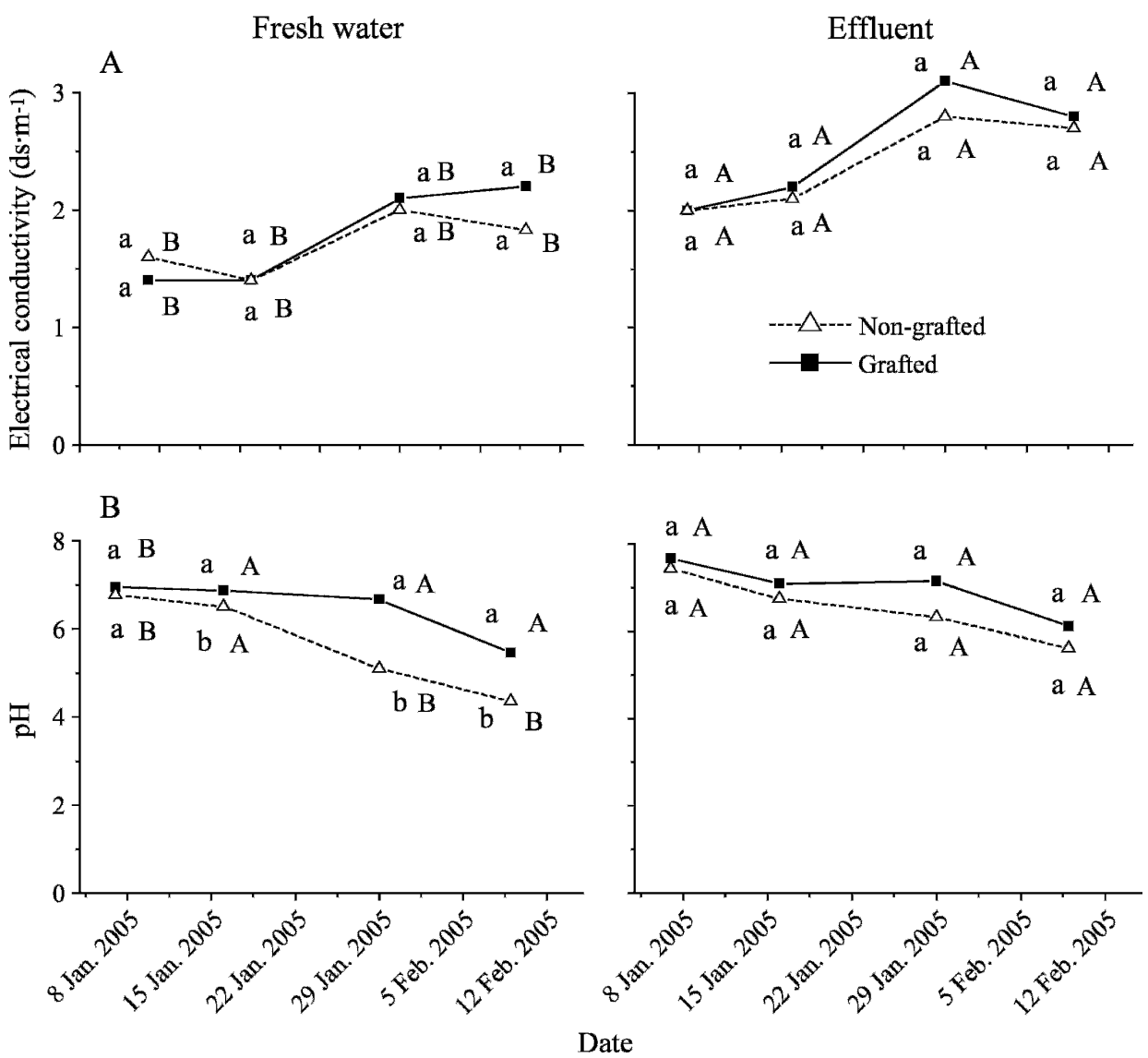

Fig. 2. (A, B) Average values of electrical conductivity and $\mathrm{pH}$ in drainage water from root zones of nongrafted and grafted melon plants irrigated with fresh water or with effluent. Different lowercase letters close to symbols indicate statistically significant (at the 0.05 level) differences between plant types for each sampling date and water irrigation type. Different uppercase letters close to symbols indicate statistically significant (at the 0.05 level) differences between irrigation water types for each sampling date and plant type.
$\mathrm{pH}$ decrease was most likely the result of root activity that released protons to the external solution. The $\mathrm{pH}$ values were lower in the leachate from the nongrafted plants than in the leachate from the grafted ones for each sampling date, but these differences were statistically significant only under freshwater irrigation (Fig. 2B). Likewise, the leachate $\mathrm{pH}$ values were higher in the effluent than in the freshwater reatment for each plant type and sampling date (Fig. 2B); significant only for the nongrafted plants. These results (Fig. 2B) indicate that the root systems of the nongrafted plants were more active in $\mathrm{pH}$ reduction than those of the grafted They also indicate that the higher dissolved organic matter content in the effluent limited the $\mathrm{pH}$ decrease in the root zone. This $\mathrm{pH}$ decrease could affect the boron absorption by the plant roots by changing the boron species in the olution. The two main boron species in aquatic solutions with $\mathrm{pH}$ less than 10 are boric acid $\left[\mathrm{B}(\mathrm{OH})_{3}\right]$ and the ion borate $\left[\mathrm{B}(\mathrm{OH})_{4}\right]$ (Bingham et al., 1985). However, boron is absorbed by plant roots mainly as boric acid (Greenwood, 1973). The $\mathrm{pH}$ of the leachate from the plant pots of all the treatments ranged from 4.4 to 7.7 (Fig. $2 \mathrm{~B}$ ) - a range in which the boric acid is the main boron carrier in aquatic solution and in which its concentration does not change with changing $\mathrm{pH}$ (Bingham et al., 1985). It can be concluded from these results (Figs. 1 and 2 ) that changes in the $\mathrm{pH}$ medium incited by the root did not give rise to the observed differences in the boron concentrations in the two plant types.

Third, differences in the selectivity of the different root systems to boron absorption could affect boron concentrations from the root system. Boron could be absorbed by the root cell symplast or loaded into the xylem by means of two main transport mechanisms: passive diffusion through the lipid bilayer or passage through proteinaceous channels in the cell membrane. The latter mechanism depends on metabolic energy, as demonstrated by Dannel et al. (2000) and Dordas and Brown (2000). For example, boron permeability coefficients of purified plasma membrane vesicles obtained from Cucurbita pepo L. (squash) roots were six times greater than those of microsomal vesicles. Boron uptake in intact $C$. pepo plants was reduced by $40 \%$ to $90 \%$ by channel transport inhibitors, and other nonelectrolytes similar in molecular size to boric acid competed with boron and thus reduced its uptake rate (Dordas et al., 2000). Although the boron permeability coefficients of melon and pumpkin membranes were not compared by Dordas and Brown (2000), it is very likely that the rates of channel-mediated transport of melon roots were significantly higher 
than those of pumpkin roots, as was found in some other species (Dordas and Brown, 2000). It can be concluded from the current results (Figs. 1 and 2) that the lower boron concentrations in the organs of the grafted plants than in the nongrafted ones (Fig. 1) were mainly the result of the lower boron uptake of the root systems of the former plants.

The total fruit yield and the dry biomass accumulated by the shoot and root decreased linearly as the boron concentration in the irrigation water increased up to $\approx 10 \mathrm{mg} \cdot \mathrm{L}^{-1}$ and, in most cases, the regression lines were statistically significant at a level of 0.05 (Fig. 3). The differences between the average weights of individual fruit in the various boron treatments were small and nonsignificant, except in nongrafted plants irrigated with fresh water (results not presented). In contrast, the decrease in the number of fruit per plant with increasing boron concentration in the irrigation water was, in general, statistically significant at the 0.05 level (results not presented). Therefore, the decrease in the total fruit yield with increasing boron concentration (Fig. 3) was mainly attributed to the decrease in the number of fruit per plant. Likewise, the total soluble solids content of the fruit decreased with increasing boron concentration in the irrigation water. It was also less in the effluent treatment than in the freshwater treatment, and in grafted versus nongrafted plants. However, because of the wide scatter of these results, the differences were, in most cases, statistically nonsignificant and therefore are not presented.

The total fruit yields of grafted and nongrafted plants, as well as their vegetative shoot and root dry weights, were all higher under freshwater irrigation than under effluent irrigation, when no boron was added to the irrigation waters (Fig. 3). This adverse effect of the effluent could have been incited by the higher $\mathrm{EC}$ and $\mathrm{pH}$ values or by higher concentrations of dissolved organic matter in the effluent than in the fresh water (Table 1). Heavy metals and boron in the effluent (Table 1) probably did not contribute to decreases in yield, because their concentrations were below toxic levels (El-Sheikh et al., 1971; Feigin et al., 1991).

The gradients of the linear regression lines (Fig. 3) may be used as indices of the plant sensitivity to boron concentration in the irrigation water. For a given organ and in a particular treatment, the steeper the gradient (i.e., the higher the absolute value of the "b" parameter in the linear regression equation), the greater the sensitivity. The gradients of the regression lines for all the plant organs were steeper under freshwater irrigation than under effluent irrigation for each plant type (Fig. 3), which indicates that the effluent mitigated the adverse effects of high boron concentration in the irrigation water on the growth and yield of melons. Likewise, for all the plant organs and for each water type, the gradients of the regression lines were steeper with the nongrafted than with the grafted plants, except for shoot dry weight under effluent irrigation (Fig. 3). It can be concluded from these results (Fig. 3) that the nongrafted plants were more sensitive than the grafted ones to high boron concentrations in the irrigation water. This issue is

discussed later.
Fig. 3. (A-C) Total fruit yields and dry weights of shoots and roots of nongrafted and grafted melon plants irrigated with fresh water or effluent as functions of boron concentration in the irrigation water, including the regression equations. Bars indicate $\mathrm{SE} ; *$ indicates that the regression line is statistically significant at the 0.05 level. 
Boron uptake in the vegetative shoot was calculated by using the equation that describes the relationship between boron concentrations in the old leaves of nongrafted and grafted melon plants, and in their entire vegetative shoot (Edelstein et al., 2005). In all the treatments of nongrafted and grafted plants irrigated with fresh water or with effluent, and also for all boron concentrations in the irrigation water, more than $80 \%$ of the total boron uptake in the plant was located in the vegetative shoot, less than $20 \%$ in the fruit, and negligible amounts were noted in the roots (Fig. 4). The low boron accumulation in the root reflected the relatively low concentration of boron in the root tissue (Fig. 1) and the low dry weight of that tissue in both plant types (Fig. 3). In contrast, the high boron uptake in the vegetative shoot mainly reflected the high boron concentration in the leaves (Fig. 1). The high boron uptake in the shoot can mainly be attributed to the transpiration rates of the leaves and the transport of boron in the transpiration water (Ben-Gal and Shani, 2002; Dannel et al., 2000; Pfeffer et al., 1999).

The relatively low accumulation of boron in the fruit is of interest, because the water content in the fruit was much higher than that in the leaves. This can be interpreted in two main ways. First, transpiration rates of fruit, per unit weight, are much less than those of leaves because of their different shape

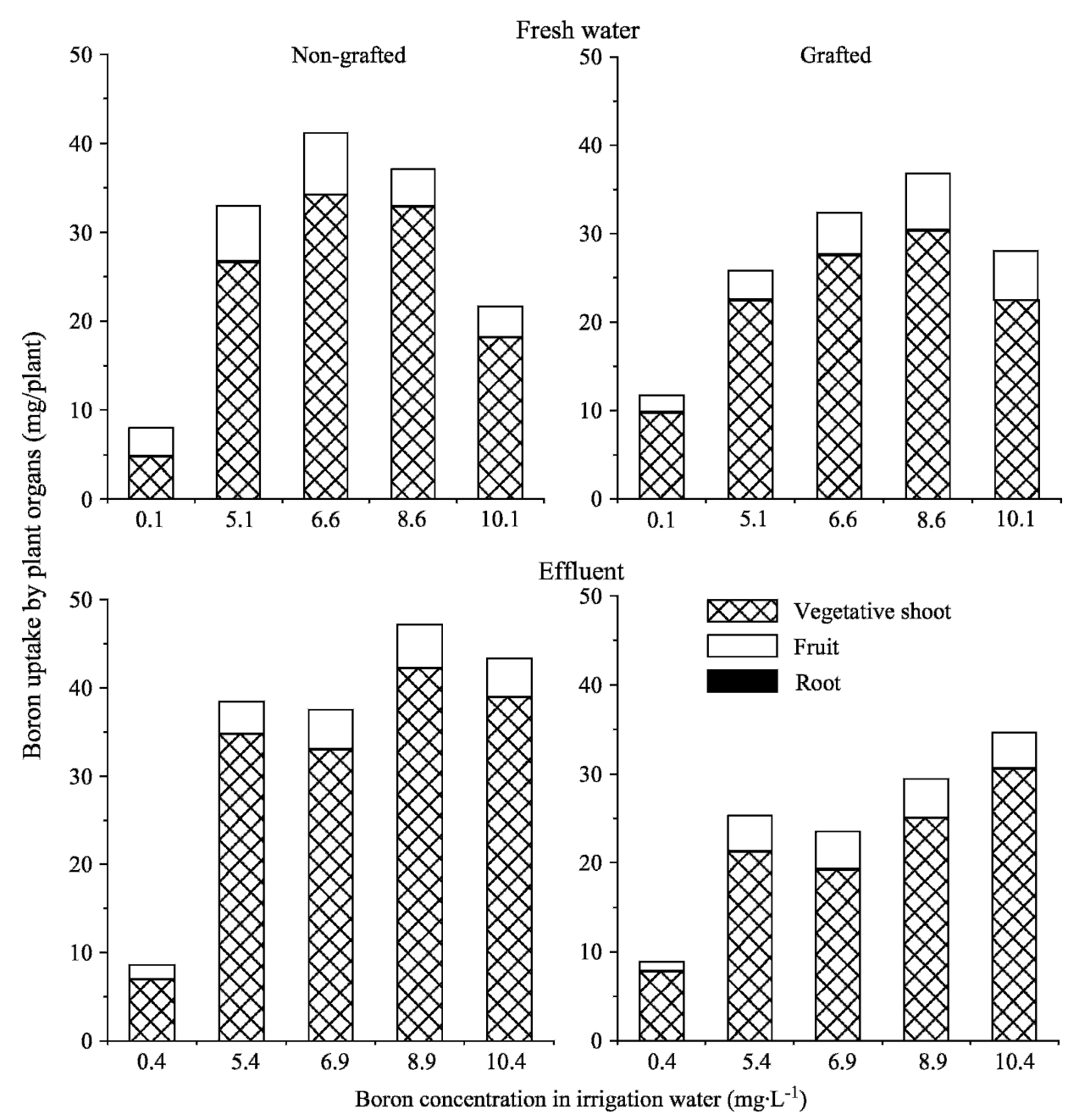

Fig. 4. Total boron uptake in various organs of nongrafted and grafted melon plants irrigated with fresh water or with effluent, with various boron concentrations. and the many fewer stomata on the fruit surface. Second, water is transported to the leaves via the xylem, whereas water to the fruit goes mainly via the phloem, as was clearly documented for tomato fruit, in which $80 \%$ to $90 \%$ of the water was transported via the phloem (Plaut et al., 2004). A similar situation may be hypothesized for melons, in light of the finding that boron is almost entirely transported via the xylem and its translocation via the phloem is minimal (Shelp et al., 1995).

The total boron uptake per plant for both plant types and both irrigation water types was $\leq 10 \mathrm{mg}$ at a boron concentration of $\leq 0.4 \mathrm{mg} \cdot \mathrm{L}^{-1}$ in the irrigation water (Fig. 4). Increased concentrations of boron in the irrigation water resulted in a steep increase in its uptake, reaching maximum values when the boron concentration was $6.6 \mathrm{mg} \cdot \mathrm{L}^{-1}$ for the nongrafted plants irrigated with fresh water, $\approx 8.5 \mathrm{mg} \cdot \mathrm{L}^{-1}$ for the grafted plants irrigated with fresh water and nongrafted plants irrigated with effluent, and $10.4 \mathrm{mg} \cdot \mathrm{L}^{-1}$ for the grafted plants irrigated with effluent (Fig. 4). The decreases in the total boron uptake as its concentration in the irrigation water increased further were incited by the declines in plant size, which overcompensated for the increases in boron concentration in the plant tissue.

The decreases in fruit yield and in the dry weights of the vegetative shoot and root with increasing boron concentration

(Fig. 3) were most likely the result of physiological damage to the plant tissues incited by boron accumulation in these plant organs (Fig. 1) (Bingham et al., 1985; Edelstein et al., 2005; Gupta et al., 1985; Keren and Bingham, 1985; Oertli and Kohl, 1961). However, because the decreases in the total fruit yields of the two melon plant types as the boron concentration in the irrigation water increased (Fig. 3) were mainly attributed to decreases in the numbers of fruit per plant and not to decreases in the average weights of individual fruit, we conclude that the decrease in the fruit yield was not the result of physiological damage to the fruit tissues.

Table 2 presents four sets of four regression equations, each applicable to the data for grafted and nongrafted plants, irrigated with fresh water or with effluent. In these calculations, the total fruit yield or the dry weight of the vegetative shoot and root system that corresponded to the lowest boron concentration in the irrigation water was designated as $100 \%$, and the boron concentration in the old leaves or in the root system in the treatment with the highest boron concentration in the irrigation water was considered as $100 \%$. The gradients of the regression lines (the absolute values of the " $b$ " parameter in the linear regression equations) indicate the percentage decreases in the fruit yield, and in the dry weights of the vegetative shoot and of the root system, per $1 \%$ 
Table 2. Linear regression equations for relative fruit yield and dry weight of vegetative shoot and root system versus relative boron concentrations in the old leaves or the roots of nongrafted and grafted melon plants.

\begin{tabular}{lcccc}
\hline Treatment & Regression equation & $r^{2}$ & Regression equation & $r^{2}$ \\
\hline & \multicolumn{2}{c}{$\begin{array}{c}\text { Fruit yield vs. boron concn } \\
\text { in the old leaves }\end{array}$} & \multicolumn{2}{c}{$\begin{array}{c}\text { Shoot dry wt. vs. boron concn } \\
\text { in the old leaves }\end{array}$} \\
Fresh water, nongrafted & $\mathrm{Y}=111-0.83 \mathrm{X}$ & 0.95 & $\mathrm{Y}=108-0.68 \mathrm{X}$ & 0.87 \\
Fresh water, grafted & $\mathrm{Y}=110-0.55 \mathrm{X}$ & 0.98 & $\mathrm{Y}=113-0.68 \mathrm{X}$ & 0.95 \\
Effluent, nongrafted & $\mathrm{Y}=109-0.62 \mathrm{X}$ & 0.99 & $\mathrm{Y}=106-0.24 \mathrm{X}$ & 0.68 \\
Effluent, grafted & $\mathrm{Y}=144-0.54 \mathrm{X}$ & 0.7 & $\mathrm{Y}=103-0.36 \mathrm{X}$ & 0.81 \\
& Fruit yield vs. boron concn in root & Root dry wt vs. boron concn in root \\
Fresh water, nongrafted & $\mathrm{Y}=165-1.51 \mathrm{X}$ & 0.91 & $\mathrm{Y}=116-1.16 \mathrm{X}$ & 0.82 \\
Fresh water, grafted & $\mathrm{Y}=165-1.11 \mathrm{X}$ & 0.96 & $\mathrm{Y}=130-0.79 \mathrm{X}$ & 0.65 \\
Effluent, nongrafted & $\mathrm{Y}=148-1.09 \mathrm{X}$ & 0.96 & $\mathrm{Y}=154-1.13 \mathrm{X}$ & 0.94 \\
Effluent, grafted & $\mathrm{Y}=132-0.71 \mathrm{X}$ & 0.81 & $\mathrm{Y}=120-0.54 \mathrm{X}$ & 0.83 \\
\hline
\end{tabular}

increase in the boron concentration in the old leaves or in the roots. The gradients of the regression lines of the total fruit yield versus boron concentration in the old leaves or in the roots were steeper for the nongrafted plants than for the grafted ones, for each water type (Table 2). It can be concluded not only that the grafted melon plants absorbed less boron than the nongrafted ones (Fig. 1), but that at any given boron concentration in the plant leaves or in the root system, they were also less sensitive to boron accumulation. Edelstein et al. (2005) reached a similar conclusion for melon plants that were irrigated with fresh (EC, $1.8 \mathrm{dS} \cdot \mathrm{m}^{-1}$ ) or saline $\left(\mathrm{EC}, 4.8 \mathrm{dS} \cdot \mathrm{m}^{-1}\right.$ ) water, but offered no explanation for this phenomenon.

It is clear that the gradients of the regression lines of the relative fruit yields versus boron concentrations in roots are steeper than those observed for old leaves, for each type of plant or irrigation water (Table 2). Likewise, the gradients of the regression lines of the root relative weights vs. boron concentrations in their tissues are steeper than those for vegetative shoot relative weights versus boron concentrations in their tissues (Table 2). These results suggest that the fruit yield was more sensitive to the boron concentration in the root system than to the boron concentration in the leaves, which could be attributed to the high sensitivity of the root system to boron concentration in its tissues. In the current case, root system development was the limiting factor in controlling fruit formation and shoot growth of melon plants under high boron concentrations. The gradients of the regression lines of the relative values of fruit yield or of dry weight of the root system versus boron concentration in the roots were steeper for the nongrafted than for the grafted plants under irrigation with each water type (Table 2), which indicates that the root system of the nongrafted plants was more sensitive to boron concentration in its tissue than that of the grafted plants.

Figure 5 illustrates the effects of the higher sensitivity of the root system of the nongrafted than that of the grafted melon plants to high boron concentration in the irrigation water. The drastically diminished size of the root system of the nongrafted plant (Fig. 5) most likely decreased the capability of this root system to absorb water and nutrients, and this, in turn, sharply decreased the fruit yields of the nongrafted plants. In contrast, the lower sensitivity of the root system (Cucurbita rootstock) of the grafted plants allowed relatively copious absorption of water and nutrients by these plants, even with high boron concentrations in the irrigation water, and this mitigated the effects of boron on the fruit yield.
The mitigating effect of effluent irrigation on the sensitivity of the root system to boron and, consequently, on the fruit yield reduction was probably a result of the higher $\mathrm{pH}$ in the root zone under this irrigation (Fig. 2). However, this issue should be investigated in more detail.
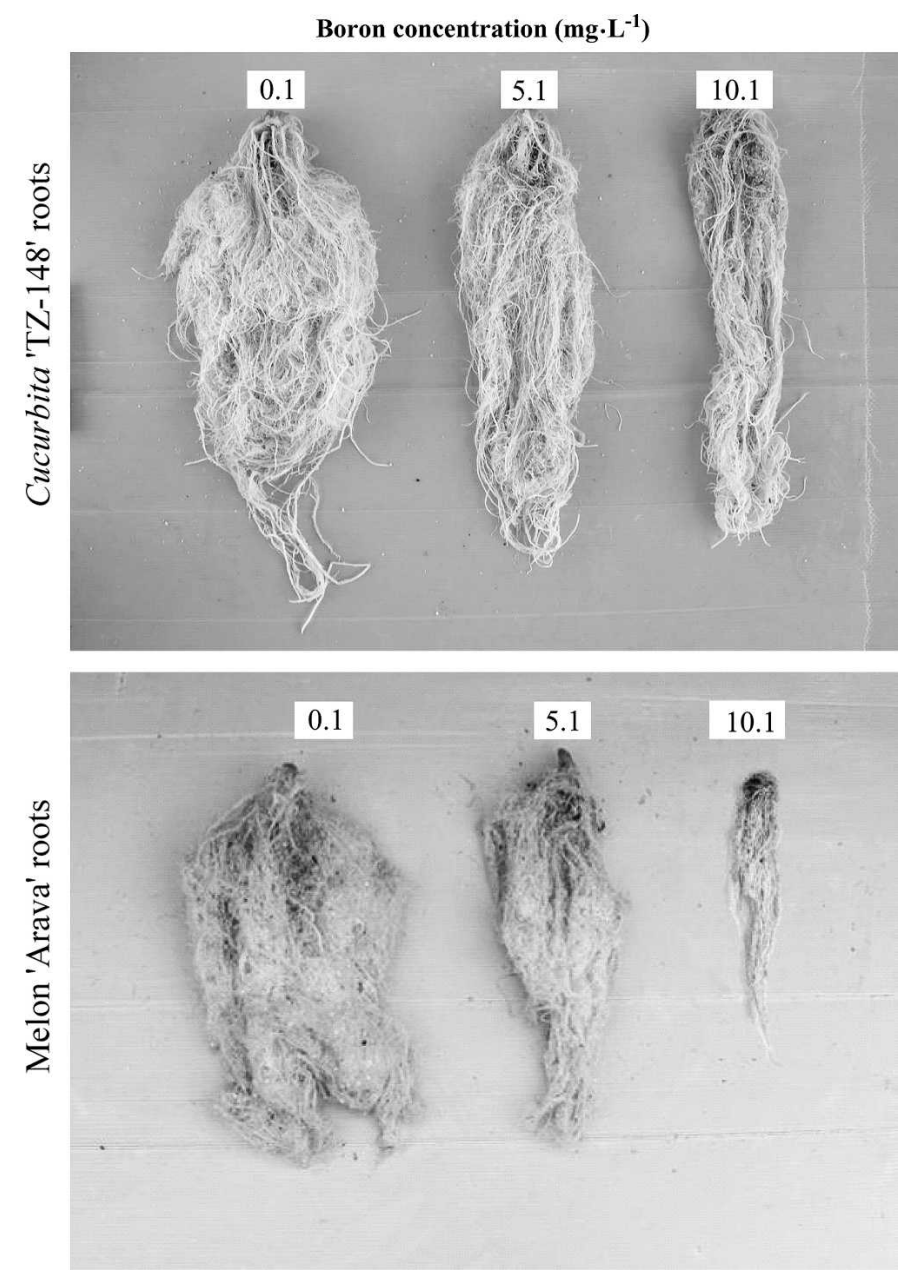

Fig. 5. Root sizes of melon and Cucurbita irrigated with fresh water as affected by boron concentrations (numbers close to the top of the root systems) in the irrigation water. 


\section{Conclusions}

Increasing boron concentration in the irrigation water significantly increased boron concentration in the plant, with most of the boron being accumulated in the leaves. Because the greatest transpiration was via the leaves, these results are a good indication that transpiration was the major determining factor for boron accumulation in the leaves.

Under both freshwater and effluent irrigation, the boron concentration was lower in the grafted plants than in the nongrafted plants, and this was mainly the result of the lower boron uptake by the root systems of the grafted plants.

Increasing boron concentration in the irrigation water up to $10 \mathrm{mg} \cdot \mathrm{L}^{-1}$ significantly decreased fruit yield and vegetative shoot and root mass in both nongrafted and grafted plants, but the nongrafted plants were more sensitive than the grafted ones to high boron concentrations. Possibly the higher boron sensitivity of the root systems of the nongrafted plants decreased their ability to absorb water and nutrients, which in turn sharply reduced their fruit yields.

Effluent decreased the sensitivity of the plants to boron, and this was probably a result of the higher $\mathrm{pH}$ in the root zone. However, this issue needs to be investigated more thoroughly.

\section{Literature Cited}

Ben-Gal, A. and U. Shani. 2002. Yield, transpiration and growth of tomatoes under combined excess boron and salinity stress. Plant Soil 247:211-221.

Ben-Gal, A. and U. Shani. 2003. Water use and yield of tomatoes under limited water and excess boron. Plant Soil 256:179-186.

Ben-Hur, M. 2004. Sewage water treatments and reuse in Israel, p. 167-180. In: F. Zereini (ed.). Water in the Middle East and in North Africa: Resources, protection, and management. Springer, New York.

Bingham, E.T., J.E. Strong, J.D. Rhoads, and R. Keren. 1985. An application of the Maas-Hoffman salinity response model for boron toxicity. Soil Sci. Soc. Amer. J. 49:672-674.

Dannel, F., H. Pfeffer, and V. Römheld. 2000. Characterization of root boron pools, boron uptake and boron translocation in sunflower using stable isotopes 10B and 11B. Aust. J. Plant Physiol. 27:397405.

Dordas, C. and P.H. Brown. 2000. Permeability of boric acid across lipid bilayers and factors affecting it. J. Membr. Biol. 175:95-105.

Dordas, C., M.J. Chrispeels, and P.H. Brown. 2000. Permeability and channel-mediated transport of boric acid across membrane vesicles isolated from squash roots. Plant Physiol. 124:1349-1361.

Eaton, F.M. 1994. Deficiency, toxicity and accumulation of boron in plants. J. Agr. Res. 69:237-277.

Edelstein, M., M. Ben-Hur, R. Cohen, Y. Burger, and I. Ravina. 2005. Boron and salinity effects on grafted and non-grafted melon plants. Plant Soil 269:273-284.

Edelstein, M., R. Cohen, S. Shreiber, S. Pivonia, and D. Shteinberg. 1999. Integrated management of sudden wilt in melons caused by Monosporascus cannonballus using grafting and reduced rates of methyl bromide. Plant Dis. 83:1142-1145.

Elmotaium, R., H.N. Hu, and P.H. Brown. 1994. The relative tolerance of six Prunus rootstocks to boron and salinity. J. Amer. Soc. Hort. Sci. 119:1169-1175.

El-Sheikh, A.M., A. Ulrich, S.K. Awad, and A.E. Mawardy. 1971. Boron tolerance of squash, melon, cucumber and corn. J. Amer. Soc. Hort. Sci. 94:536-537.
Estan, M.T., M. Martinez-Rodriguez, F. Perez-Alfocea, T.J. Flowers, and M.C. Bolarin. 2005. Grafting raises the salt tolerance of tomato through limiting the transport of sodium and chloride to the shoot. J. Expt. Bot. 56:703-712.

Feigin, A., I. Ravina, and J. Shalhevet. 1991. Irrigation with treated sewage effluent. Springer, New York.

Goldberg, S., P.J. Shouse, S.M. Lesch, C.M. Grieve, J.A. Poss, H.S. Forster, and D.L. Suarez. 2003. Effect of high boron application on boron content and growth of melons. Plant Soil 256:403-411.

Greenwood, K. 1973. Boron, p. 665-691. In: J.C. Bailar, H.J. Emeleus, R. Nyholm, and A.E. Trotman-Dickenson (eds.). Comprehensive inorganic chemistry. Vol. I. Pergamon Press, Oxford, UK.

Gupta, U.C., Y.W. James, C.A. Campbell, A.J. Leyshon, and W. Nicholaichuk. 1985. Boron toxicity and deficiency: A review. Can. J. Soil Sci. 65:381-409.

Halliwell, D.J., K.M. Barlow, and D.M. Nash. 2001. A review on the effects of wastewater sodium on soil physical properties and their implications for irrigation systems. Aust. J. Soil Res. 39:1259-1267.

Johns, G.G. and D.M. McConchie. 1994. Irrigation of bananas with secondary treated sewage effluent. 2. Effect on plant nutrients, additional elements and pesticide residues in plants, soil and leachate using drainage lysimeters. Austral. J. Agr. Res. 45:1619-1638.

Keren, R. and F.T. Bingham. 1985. Boron in water, soil and plants. Adv. Soil Sci. 1:229-276.

Lauter, D.J., A. Meiri, and U. Yermiyahu. 1989. Tolerance of peanut to excess boron. Plant Soil 114:35-38.

Marschner, H. 1989. Mineral nutrition of higher plants. 2nd ed. Academic Press, New York.

Nable, R.O., G.S. Banuelos, and J.G. Paull. 1997. Boron toxicity, p. 181-198. In: B. Dell, P.H. Brown, and R.W. Bell (eds.). Boron in soil and plants. Kluwer, Dordrecht, the Netherlands.

Oertli, J.J. and H.C. Kohl. 1961. Some considerations about the tolerance of various plant species to excessive supplies of boron. Soil Sci. 92:243-247.

Papadakis, I.E., K.N. Dimassi, A.M. Bosabalidis, I.N. Theprios, A. Patakas, and A. Giannakoula. 2004. Boron toxicity in clementine mandarin plants grafted on two rootstocks. Plant Sci. 166: 539-547.

Pfeffer, H., F. Dannel, and V. Romheld. 1999. Are there two mechanisms for boron uptake in sunflower? Plant Physiol. 155: 34-40.

Plaut, Z., A. Grava, C. Yehezkel, and E. Matan. 2004. How do salinity and water stress affect transport of water, assimilates and ions to tomato fruits? Physiol. Plant. 122:429-442.

Poss, J.A., S.R. Grattan, C.M. Grieve, and M.C. Shannon. 1998. Characterization of leaf boron injury in salt-stressed Eucalyptus by image analysis. Plant Soil 206:237-245.

Reboll, V., M. Cerezo, A. Roig, V. Flors, L. Lapena, and P. GarciaAgustin. 2000. Influence of wastewater vs groundwater on young citrus trees. J. Sci. Food Agr. 80:1441-1446.

Shelp, P.J., E. Marentes, A.M. Kitheka, and P. Vivekanandan. 1995. Boron mobility in plants. Physiol. Plant. 94:356-361.

Tsadilas, C.D. 1997. Soil contamination with boron due to irrigation with treated municipal waste water, p. 265-270. In: R.W. Bell and B. Rerkasem (eds.). Boron in soil and plants. Kluwer, Dordrecht, the Netherlands.

U.S. Department of Agriculture. 1954. Diagnosis and improvement of saline and alkaline soils. Handbook no. 60. U.S. Dept. Agr., Washington, DC.

Yermiyahu, U., R. Keren, and Y. Chen. 1995. Boron sorption by soil in the presence of composted organic matter. Soil Sci. Soc. Amer. J. 59:405-409.

Zekri, M. and R.C.J. Koo. 1994. Treated municipal waste-water for citrus irrigation. J. Plant Nutr. 17:693-708. 